\title{
Recruitment Methods at the Travel Agencies in Egypt: Risks and Costs.
}

\author{
Dr. Soha Bahgat
}

\begin{abstract}
It's understandable that the tourism sector is very unique in the sense that it has its very own characteristics and profile of its employees, besides to the scope of responsibilities they need to handle as well as how presentable they should be. This case is way more relevant in Egypt with the economic challenges facing the country from one side and the robust intention to improve the tourism sector on a national level as a potential provider for foreign currency to the national economy from the other side. Although this might seem at first sight as a threats-free opportunity, however, in reality, this is not the case. Looking into recruitment methods used by the travel agencies it became apparent the existence of some serious drawbacks whether in the process of recruitment or in the processes that follows. This paper aims at exploring the current recruitment mechanisms in the Egyptian travel agencies and studying the concepts underlying their selection criteria, their reactions towards new trends in the market in order to propose solutions to enhance labor force quality in travel agencies. Therefore, the research question of this paper can be stated as: How good are current recruitment mechanisms in Egyptian travel agencies and how far do they adapt to new technologies.
\end{abstract}

Key words: Travel Agencies, recruitment, risks, loyalty, skills, gap.

\section{Introduction}

Almost one million job-seeker join the Egyptian labor market every year, each of these job seekers has to go through certain different processes to get accepted to a job (Kot, 2008). These processes, whether long or short, have certain objectives and aims which when met leads to more efficient and productive employees and overall firm productivity. On the other hand, when these processes are not done correctly they can lead to high turn-over rates and/or very low retention rates (Boswell et.al, 2013). These different processes are what we call "The Recruitment Process". This paper would focus on the recruitment methods applied by the Egyptian travel agencies and their adoption to the new trends in the E-tourism market. Interestingly, there is a serious gap between the needed profile of the people working in the traveling agencies and what the markets has to offer in terms of unskilled candidates for the vacant jobs in these traveling agencies.

The market for travel operators has witnessed serious developments of new trends in the last few decades; these developments need to be reflected in the type of services that the travel agencies provide and in turn in the profiles of the employees of the travel agencies. The topic of the research is a very important topic due to the nature of Egypt as a worldwide tourist destination. 
This significance of the tourism sector has been magnified recently with the responsibility the tourism sector bears of providing foreign currency to the whole country in the midst of the economic slowdown that the whole country witnessed.

\section{Theoretical Framework and Key Concepts}

Many academic literatures in human resources management define recruitment (hiring) as the core function of human resource management. Recruitment refers to the overall process of attracting, selecting and appointing suitable candidates for jobs (either permanent or temporary) within an organization. Recruitment can also refer to processes involved in choosing individuals for unpaid positions, such as voluntary roles or unpaid trainee roles.

The recruitment process is designed to furnish the organization with the new employees, and it uses many different recruitment sources to attract the right talents in the defined quality and within a defined time (Ahmad \& Schroeder, 2002; Khanna, 2012).

\section{Recruitment Process}

The recruitment process has the primary objective of hiring the most suitable candidate for the vacancy; however, there are some other secondary aims for this process (Wilson, 2001; Leung 2014) such as enhancing the outreach and the visibility of the company, improving the productivity of the company and enhancing the company's perception of the labor market and its mechanisms (Tylor \& Collins, 2013; Koch\& McGrath, 2016). The recruitment process goes through certain steps that are predefined by Human Resources Development (HRD) specialists and in Human Resources literature. These steps are identification of the needs and initiating the search, determining the selection criteria, defining the channel of advertisement, screening of the applicants, interviewing and selecting and orientation and integration of the new employees (Wilson, 2001\& Anderson, 2003).

\section{Threats and Limitations of the Recruitment Process}

Recruitment is a process that is affected by both internal and external factors, unfortunately these factors can attribute greatly to the success of the process and the satisfaction of both the employee and the employers (Anderson, 2003). Among the internal limitations and/or threats to the recruitment process is misidentifying of the needs of the company and this can lead to an inefficient recruitment process. Further, these internal threats and limitations can be eliminated under the right human resources management of the company (Chan 2016). On the other side, the limitations and threats to the recruitment process are more serious, due to the fact that they are not under the control of the firm (Wong, et al., 1997; Rogg, 2012). Limitations like; the lack of qualified candidates or the lack of suitable advertising channel or the high cost of recruiting qualified candidates. 


\section{Methodology}

The research would follow both descriptive quantitative and qualitative approaches in order to collect an accurate representation of data. The researcher chose the quantitative approach to measure certain quantifiable characteristics across a sample of travel agencies. The research tool used was a survey that was developed by the researcher and revised by a group of academic and professional experts. This research sample is composed of 16 travel agencies on stratified base selected. The investigated 16 travel agencies are all located in Cairo for geographical relevance and logistical ease. To the purpose of serving the research question, it was decided that study sample will include only welldeveloped travel agencies with established human resources department. These 16 agencies were chosen based on a series of one-to-one meetings and visits to stand on the agencies that would serve the purpose of this research question. The survey investigated 16 travel agencies in Cairo and it was conducted in 2016. Thereby, the results might not account for all the changes the country has went through after the floating of the Egyptian Pound. This might resulted in changing the eco-system of the travel agencies and tourism as a whole.

The survey was administered person to person to assure reliability and validity of survey questions. Data collected was analyzed using Excel Statistical Package v.20. Percentage analysis was used to find relations and interpret them.

The secondary data in the paper represents the extensive desk research that the research reviewed throughout the process of the drafting the paper. These documents included academic journals, books and articles in periodicals. A list of the cited works is provided at the end of the paper.

\section{Travel Agencies: A field survey}

A survey has been conducted with sixteen Egyptian tourism companies located in Cairo governorate in order to identify the recruitment and selection methods adopted by travel agencies in the tourism industry. The survey was conducted with the mangers of the traveling agencies in order to investigate the methods they use for recruitment as well as the pros and cons of each of them. The questions were in two forms; written questionnaire and short semi-structured interviews. The survey was mainly targeting the top management in order to get a macro view and the overall effects of the recruitment process. Additionally, in the written questionnaire they were asked to rank some of the problems they mentioned in the interviews.

It was found that $57.8 \%$ of the sample have recruitment and selection department in their organization. Whereas $42.1 \%$ mentioned that they don't have this department in their organization chart. They also stated that "this process is to be done by the top management or by employees in the departments which request hiring new employees. For instance, when a marketer is needed to be hired, then the marketing manager will have a significant role in the selection process and the General Manager will recruit". 
In addition, $47.4 \%$ of the interviewees preferred to hire already trained stuff while $31.6 \%$ preferred hiring new hand employees and train them. Another important point that many of the employers at the traveling agencies "didn't mind investing in professional skills' trainings, however, they don't prefer investing in their employees' soft skills" this results in high turn-over rate of employees in agree with (Ahmed, 2010).

Moreover, $57.9 \%$ of the interviewees see that it is of basics that the companies' policies work to on assuring the loyalty of the staff and assuring that the company success is in synergy with workers in a way that improves their living standards. However, around $42.1 \%$ of interviewees don't see that their companies' policy has to care about their employees' loyalty (Soupata, 2005; Turban and Greening, 2016).

This raises another issue, the lack of the human resources capabilities to bridge the gap between what is needed and what is available in the labor market. This challenge is coupled with the challenge of the lack of qualified labor force due to several reasons. Most important of these reasons is the supply-driven educational system and the brain drain of the labor force to other countries. These problems are mainly traced to lack of loyalty among employees whom retention rate is very low in a way that does not permit them to build on experience. This issue was addressed. Means by which companies build loyalty among staff were investigated. The following diagram depicts the application of these means.

\section{Benefits of using recruitment and selection process}

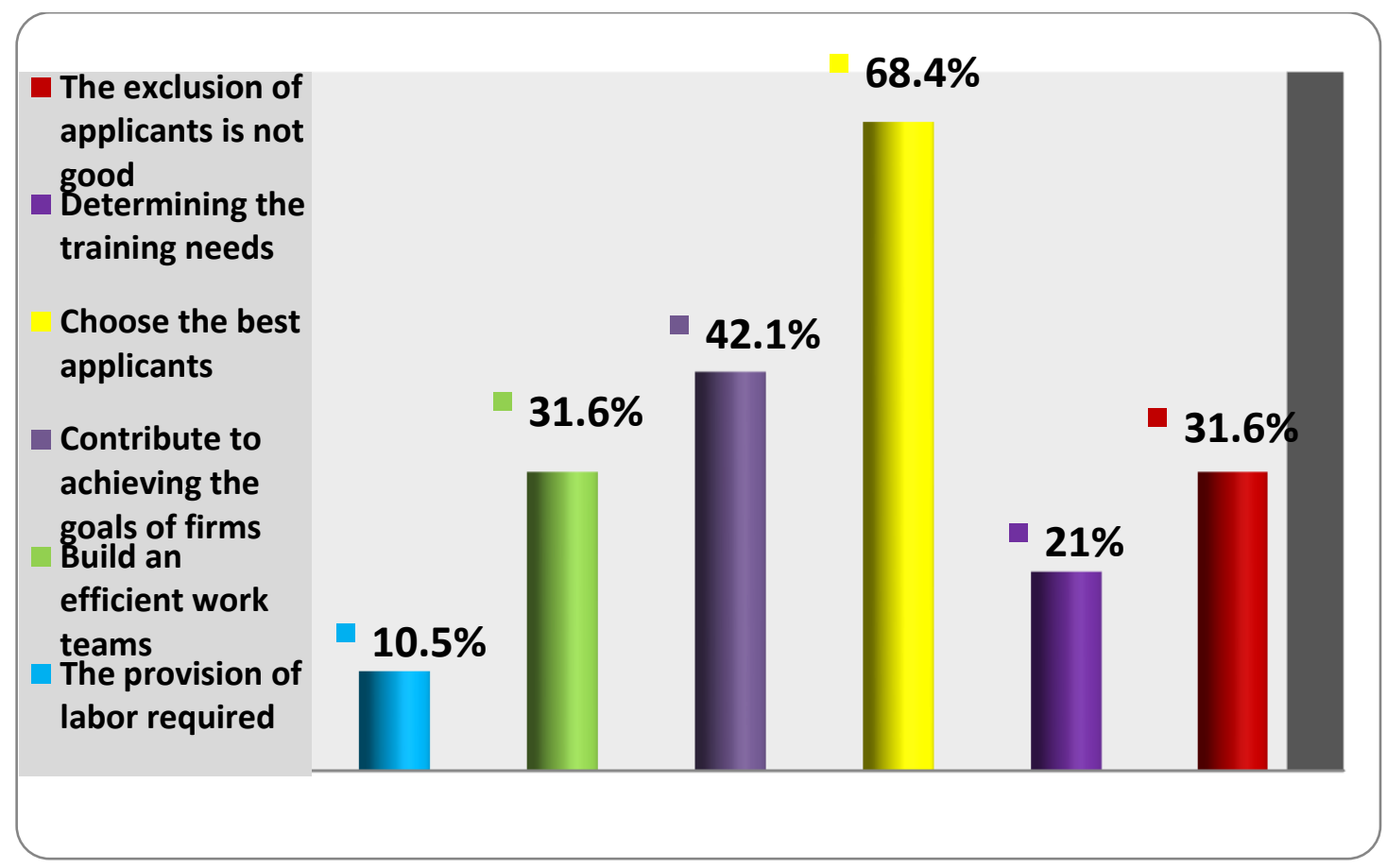

Figure (1): Priorities of recruitment for travel agencies investigated. 
The surveyed agencies believed in the importance of utilizing the recruitment process for their benefits. Selecting the best applicants came first with $68.4 \%$, contributing to company goals came second $42.1 \%$, building an efficient working team came third $31.6 \%$, determining the training needs is well served through an efficient recruitment process came fourth $21 \%$, lastly, the provision of the required labor came with $10.5 \%$. This means that the main two targets of recruitment process among travel agencies investigated are to select the best candidates in order to contribute to the achievement of the company goals. Surprisingly, building teams was not one of the main goals and came third to the first two targets. It is also clear that upon recruitment, travel agencies do not do this just to provide employees but rather to provide proper ones who can contribute to the success of the firm. Risks associated with the recruitment process were also addressed. Figure(2) best illustrates this.

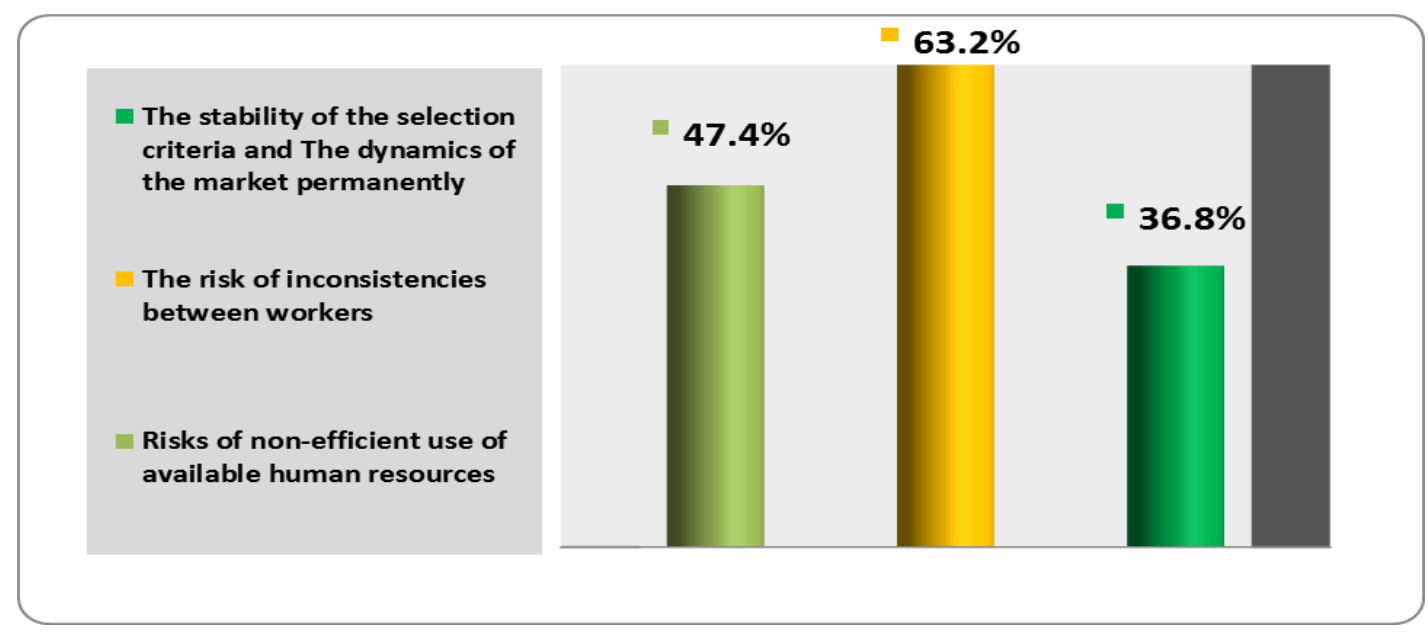

Figure (2): Risks associated with recruitment in travel agencies investigated.

The stability of the selection criteria and the dynamics of the market weight by $36.8 \%$. Additionally, the risk of inconsistencies among workers weighted $63.2 \%$. The risk of non-efficient use of available human resources weighted $47.4 \%$.

Moreover, costs associated with the recruitment process were also addressed

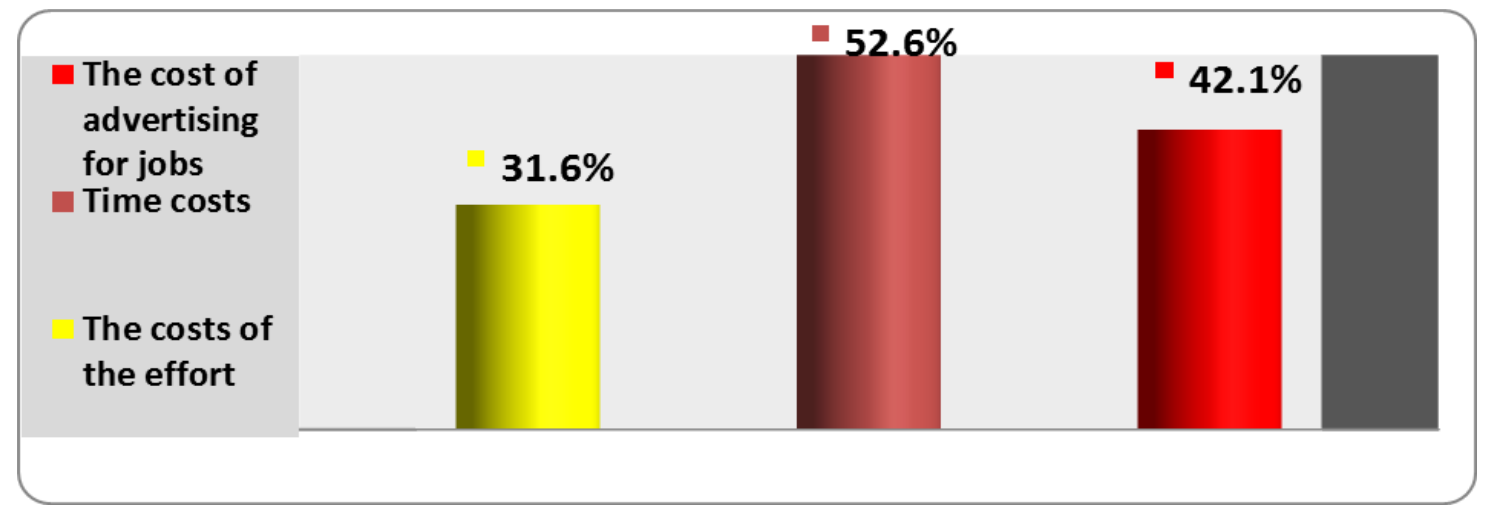

Figure (3): Costs associated with recruitment in travel agencies investigated. 
In figure (3) Costs associated with recruitment process are listed to include time cost, weights $52.6 \%$, this is the time taken to fully recruit a new applicant. The cost of advertising for jobs came second $42.1 \%$ and lastly, the cost of effort, weights $31.6 \%$.

The interviewees were also asked to reveal their main encounters with job candidates. Answers of the investigated travel agencies showed main six areas of concern. Figure (4) shows these areas and their weights relative to their importance:

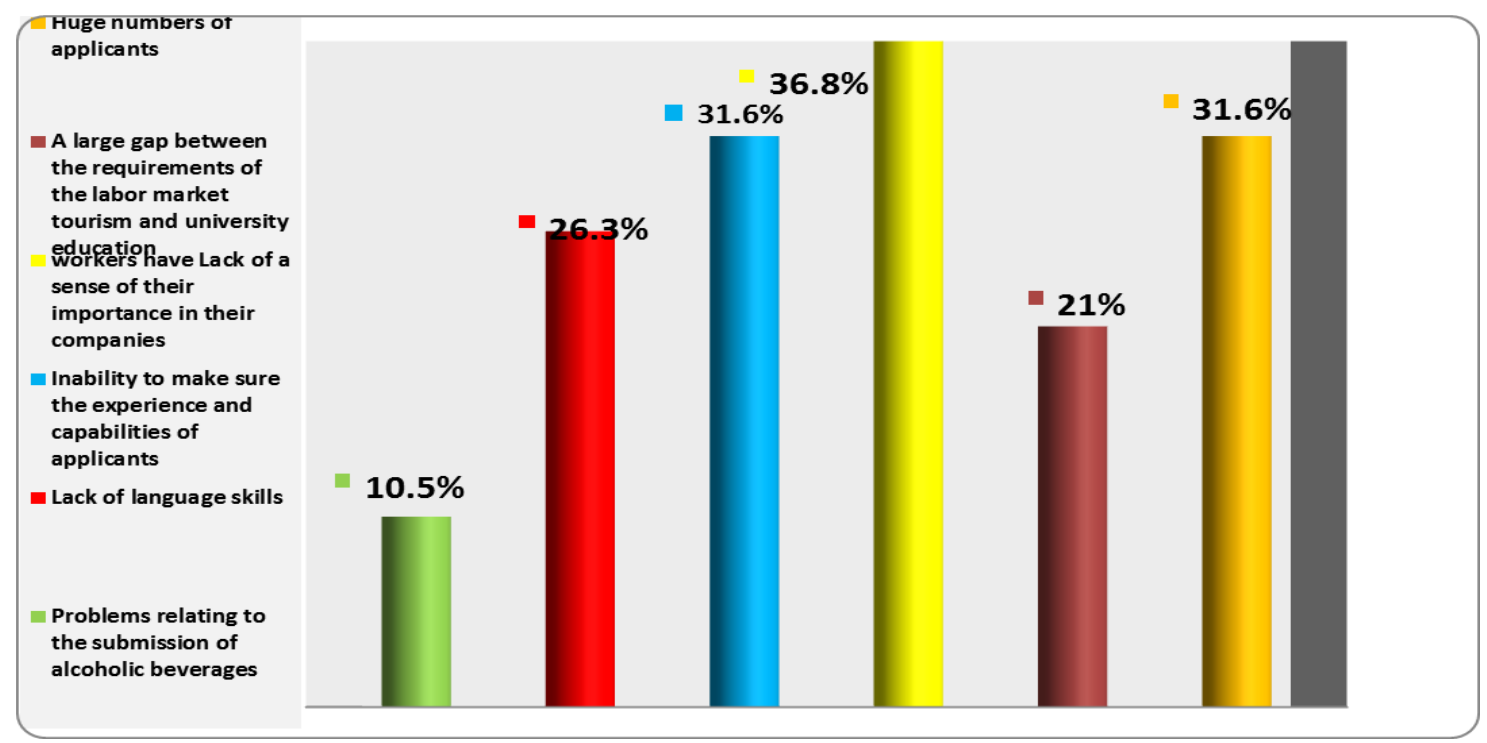

Figure (4): Areas of concern among travel agencies relative to job candidates

As shown in the chart, the most prominent problems that encounter the recruitment and selection process varied greatly. The most prominent reported problem was the lack of job importance in their companies came with $36.8 \%$. The agency's inability to validate the experiences and the certifications of the applicants as well as the presence of a huge number of applicants both came second with $31.6 \%$. Travel agencies reported that the presence of too many applicants sometimes hinders the recruitment process and makes it rather a tiring one. The lack of language skills came next $26.3 \%$. The gap between the job requirement skills and education provided skills is mirrored in the quality of the applicants This agrees with one of the HRM quotation that "tourist educational system doesn't provide the students with the needed skills and vision about their career paths"and that "there is a gap between what fresh graduates expect of the job and what the job expects from them-this is a fact in the job market" This problem came with $21 \%$. Additionally, the problems relating to serving alcoholic beverages came last with $10.5 \%$.

For better understanding of the case, a Pearson Product-moment correlation was made to explore the correlation between company perception of what they need out of recruitment procedures and actual performance or what they actually get from these procedures. Person Product - moment correlation results are shown in Table (1). 
The results indicate a strong correlation between perception and performance of travel agencies where choosing the right candidate proved to be highly significant $(r=1)$, achieving company goals was also highly significant $(r=0,752)$, building teams $(r=0.747)$, satisfying requirements $(r=0.338)$ and mere provision of staff $(r=0.714)$. A positive correlation between perception and performance is always seen for all recruitment procedures which mean travel agencies have good vision in reference to their needs during recruitment process and those they - on practicing recruitment- they achieve their targets $(r=0.843)$. In other words, travel agencies do materialize their perceptions at almost $84 \%$. Risks thus remain intact in almost $16 \%$. Risks shown in figure (2). These risks associate with costs of recruitment that are "time, effort and the adv., itself"(see Figure 3).

\begin{tabular}{|c|c|c|}
\hline & & WBT Characteristics \\
\hline \multirow{2}{*}{ Choosing best candidate } & Pearson Correlation & \multirow{2}{*}{1} \\
\hline & Sig. (2-tailed) & \\
\hline \multirow{2}{*}{ Achieving company goals } & Pearson Correlation & $0.752^{* *}$ \\
\hline & Sig. (2-tailed) & 0.000 \\
\hline \multirow{2}{*}{ Building a team } & Pearson Correlation & $0.747^{* *}$ \\
\hline & Sig. (2-tailed) & 0.000 \\
\hline \multirow{2}{*}{ Satisfying requirements } & Pearson Correlation & $0.338^{* *}$ \\
\hline & Sig. (2-tailed) & 0.000 \\
\hline \multirow{2}{*}{ Only provision of staff } & Pearson Correlation & $0.714^{* *}$ \\
\hline & Sig. (2-tailed) & 0.000 \\
\hline
\end{tabular}

\section{Commentary and Analysis}

\section{Traveling Agencies Recruitment Challenges}

One of the most important internal drawbacks of recruitment is lack of funds allocated for the recruitment process in the travel agencies, which in turn can be attributed to the deterioration in the volume of business of these agencies after the drop of the tourists' influx to Egypt in the aftermath of 2011's uprisings (Feteha, 2016). Another problem that is internal in nature is the misuse of advertising channels to announce vacancies, meaning that agencies tend to use sophisticated recruitment parameters for low skilled jobs while loosen them for high skilled job (Kot, 2008). These internal problems can be addressed through direct capacity buildings and/or workshops to the travel agencies relevant staff to the recruitment (Aladwan, et al., 2015). 
In addition to this, the absence of HRD and HRM practices inside the traveling agencies, this is manifested in the dependence on inefficient recruitment methods, the flaws of the integration and orientation trainings, lack of efficient $M \& E$ tools that adequately measures the productivity of the employees

From another perspective, challenges in the recruitment methods of traveling agencies can also be traced to some external factors. These factors may include the brain drain of skilled workers to the Gulf region and/or other booming tourist destinations (Afiouni, et al., 2013). This is due to the higher remuneration of the workers in the tourism sector in these destinations. Additionally, sometimes the discrepancy between the expectations of the job seekers and the reality of the job markets leading to hinder the recruitment process. This problem can be resulting from the lack of sufficient practical training in the educational system and/or the deficiency of transition to employment trainings that leave the potential job seekers clueless and it causes harm to their career choices.

\section{Conclusion}

Based on the findings of the paper, it's evident that there is a lack of qualified labor force in the travel agencies due to many reasons. Among these reasons is the un-readiness of the travel agencies themselves to recruit the needed human resources. The survey suggested that this is due to the poor performance of human resources departments, if they exist, at travel agencies as well as the absence of a clear HRM and HRD strategies in the most of the surveyed traveling agencies. Consequently these results suggest the significance of working on building the capacities of the traveling agencies. This capacity building should focus on the areas of recruitment in order to allow them to improve their recruitment techniques and to adapt to the changing circumstances of the tourism traveling agencies' market.

\section{Recommendations}

- Creating linkages between the educational institutions and the traveling agencies through integrated internship programs.

- Establishing training units inside the well-established travel agencies through designing an incentive system for the agencies to implement such measures.

- Creating capacity building trainings for HR managers/officials at traveling agencies on recruitment techniques.

- Consulting with the traveling agencies chambers to stand on the main issues and concerns that face the recruitment process and find feasible solutions.

- Linking the many educational curricula with the labor markets needs to bridge the gap between the markets needs and the graduates qualifications.

- Working on enhancing the work conditions of employees working in the traveling agencies to improve their retention rate. 


\section{References}

Afiouni, F., Karam, C. M. \& El-Hajj, H., 2013. The HR value proposition model in the Arab Middle East: identifying the contours of an Arab Middle Eastern HR model. The International Journal of Human Resource Management, pp. 1859-1932.

Ahmed, G., 2010. Employment and Human Resource Services in Egypt. Master's Project Duke University Sanford School of Public Policy.

Aladwan, K., Bhanugopan, R. \& D'Netto, B., 2015. The effects of human resource management practices on employees' organisational commitment. International Journal of Organizational Analysis, pp. 472-492.

Al-Faleh, M., 1987. Culture Influences on Arab Management Development: a Case Study of Jordan. Journal of Management Development, pp. 19-33.

Anderson, N., 2003. Applicant and Recruiter reactions to new technology in selection: a critical review and agenda for future research. International Journal for Selection and Assessment , pp. 121-136.

Anon., 2015. IMF Offers Support to Egypt's Economic Policies. New York Times, February .

Aycan, Z., Al-Hamadi, A. B., Pawan, A. \& Pawan, B., 2007. Cultural Orientations and Preferences for HRM Policies and Practices: The Case of Oman. International Journal of Human Resources Management, pp. 11-32.

Bartram, D. (2000), Internet Recruitment and Selection: Kissing Frogs to find Princes. International Journal of Selection and Assessment, 8: 261-274.

Beatrice, S., 2013. The Impact and Perspectives of The E-Tourism At a Global Level. Romanian Economic and Business Review.

Boswell W.R., Roehling M.V, and Le Pine MA., Moyniham L., 2013, Individual jobchoice decisions and the impact of job attributes and recruitment practices: A longitudinal field study,library Wiley , Volume 42, Issue 4, Pages 303-320

Chan w., 2016, External Recruitment versus Internal Promotion, Journal of Labor Economics14, no. 4, 555-570.

Koch M.J, Mc Garth R.G, 2016, Improving Labor Productivity: Human Resource Management Policies do Matter, Strategic Management Journal, Wiley, Vol. 27, No. 5, pp. 335-354

Condratov, I., 2013. E-tourism: Concept and Evolution. EcoForum.

Darrag, M., Mohamed, A. \& Abdel Aziz, H., 2010. Investigating recruitment practices and problems of multinational companies (MNCs) operating in Egypt. Education, Business and Society: Contemporary Middle Eastern Issues, pp. 99-116.

Feteha, A., 2016. Egypt's Tourism Collapse Stretches From the Pyramids to the Beach. Bloomberg. 
Khanna, P., 2012. Recruitment \& Selectionll. International Journal of Application for Innovation in Engineering \& Management (IJAIEM).

Koch M.J, Mc Garth R.G, 2016, Improving Labor Productivity: Human Resource Management Policies do Matter, Strategic Management Journal, Wiley, Vol. 27, No. 5, pp. 335-354

Kot, G. E., 2008. A survey of recruitment and selection practices in Egypt.. Education, Business and Society: Contemporary Middle Eastern Issues, pp. 200-212.

Leung A., 2014, Different ties for different needs: Recruitment practices of entrepreneurial firms at different developmental phases, Resource Management in SMEs, pp123:135

Queensland Tourism Industry Council, 2013. Best Practice Research:Attraction, recruitment and retention within the Queensland Tourism Industry, Queensland: Queensland Government.

Rogg K.L., Schmidt D.B. and Shull. C., 2012, Human resource practices, organizational climate, and customer satisfaction, Human resources management, Volume 43 , Issue 2 , Pages 303-320

Soupata L, 2005, Engaging employees in company success: The UPS approach to a winning team,Human Resources Management, Vol,18 No,4, pp21-26

Torchia, A., 2015. Egypt economic policies starting to pay off, IMF says. Reuters.

Turban D. and Greening D.W, 2016, Corporate Social Performance And Organizational Attractiveness To Prospective Employees, Human Resources, Vol 16, No 6, pp 173:189.

Urbano, D. \& Yordanova, D., 2008. Determinants of the Adoption of HRM Practices in Tourism SMEs. Service Business, pp. 167-185.

Wilson, J. P., 2001. Human Resources Development. Glasgow: Bell \& Bain Ltd.

Wong, C., Marshall , N., Alderman, N. \& Thwaites, A., 1997. Management training in small and medium sized enterprises: methodological and conceptual issues. The International Journal of Human Resources Management , pp. 44-65.

World Bank, 2009. Transforming Egypt: A Development Policy Review., s.l.: s.n. 


\section{طرق التوظيف في وكالات السفر في مصر: المخاطر والتكاليف}

\section{الملخص العربي}

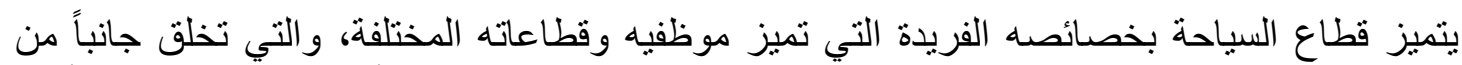

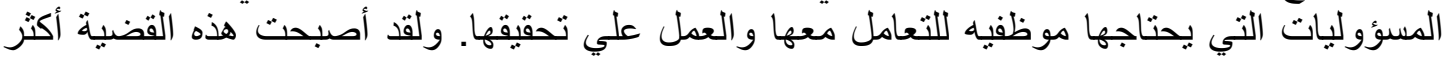

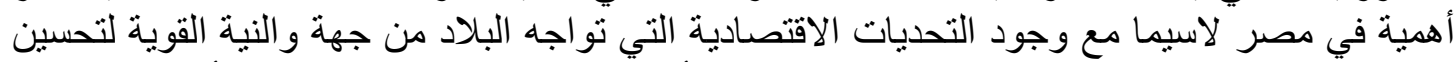
قطاع السياحة علي المستوي الوطني كمصدر للعملة الأجنبية للاقتصاد الوطني من جهة أخردي. و علي الرغم من أن هذا قد يبدو لأول وهلة علي أنه فرصة خالية من التهديدات، فإن الأمر ليس كذللك

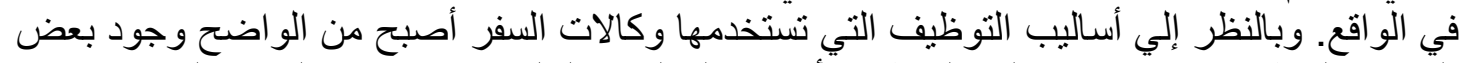

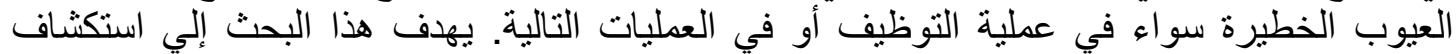

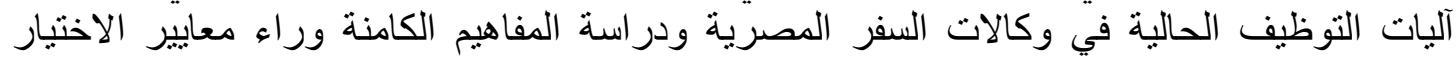

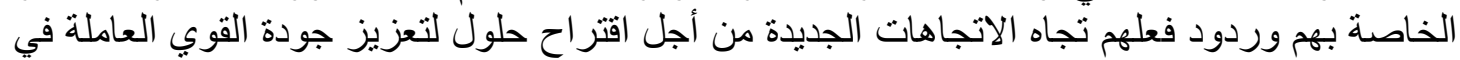

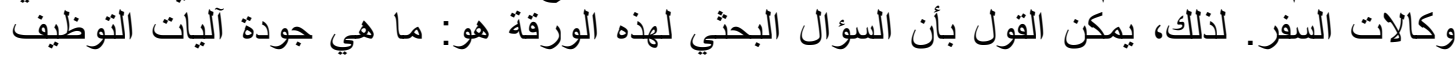

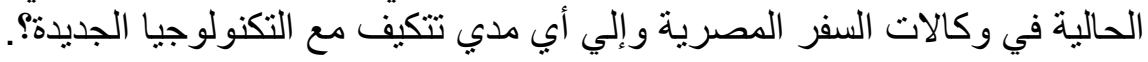

